\title{
Ectoparasite activity during incubation increases microbial growth on avian eggs
}

\author{
G. Tomás ${ }^{1, *}$, D. Martín-Gálvez ${ }^{1,2}$, C. Ruiz-Castellano ${ }^{1}$, M. Ruiz-Rodríguez ${ }^{1}$, J.M. \\ Peralta-Sánchez $^{3}$, M. Martín-Vivaldi ${ }^{3}$ and J.J. Soler ${ }^{1}$
}

${ }^{1}$ Estación Experimental de Zonas Áridas (EEZA-CSIC), Almería, Spain

${ }^{2}$ Present address: European Molecular Biology Laboratory, European Bioinformatics Institute, Wellcome Genome Campus, Hinxton, Cambridge, United Kingdom

${ }^{3}$ Facultad de Ciencias, Universidad de Granada, Spain

*Corresponding author: Email: gtomas@eeza.csic.es. Tel: (+34) 950281045. Fax: (+34) 950277100. ORCID: 0000-0001-6701-2055

\section{Acknowledgements}

We thank Estefanía López for lab work, and Tomás Pérez-Contreras and Emilio Pagani-Núñez for facilitating collection of some of the flies used in manipulations. We also thank Ángela Martínez-García for help with management of ARISA data and Natalia Juárez and Deseada Parejo for the pictures of owls and roller clutches, respectively. We appreciate the comments provided by Dr. Adèle Mennerat and five anonymous referees on earlier versions of the manuscript. Financial support was provided by Spanish Ministerio de Economía y Competitividad and FEDER (CGL2013-48193-C3-1-P, CGL2013-48193-C3-2-P), by JAE programme to DMG and MRR, and by Juan de la Cierva and Ramón y Cajal programmes to GT. All procedures were conducted under licence from the Environmental Department of the Regional Government of Andalucía, Spain (reference SGYB/FOA/AFR). All applicable international, national, and/or institutional guidelines for the care and use of animals were followed. 
1 While direct detrimental effects of parasites on hosts are relatively well documented,

2 other more subtle but potentially important effects of parasitism are yet unexplored.

3 Biological activity of ectoparasites, apart from skin injuries and blood-feeding, often

4 results in blood remains, or parasite faeces that accumulate and modify the host

5 environment. In this way, ectoparasite activities and remains may increase nutrient

6 availability that may favour colonization and growth of microorganisms including

7 potential pathogens. Here, by the experimental addition of hematophagous flies (Carnus

8 hemapterus, a common ectoparasite of birds) to nests of spotless starlings Sturnus

9 unicolor during incubation, we explore this possible side-effect of parasitism which has

10 rarely, if ever, been investigated. Results show that faeces and blood remains from

11 parasitic flies on spotless starling eggshells at the end of incubation were more abundant

12 in experimental than in control nests. Moreover, eggshell bacterial loads of different

13 groups of cultivable bacteria including potential pathogens, as well as species richness

14 of bacteria in terms of Operational Taxonomic Units (OTUs), were also higher in

15 experimental nests. Finally, we also found evidence of a link between eggshell bacterial

16 loads and increased embryo mortality, which provides indirect support for a bacterial-

17 mediated negative effect of ectoparasitism on host offspring. Trans-shell bacterial

18 infection might be one of the main causes of embryo death and, consequently, this

19 hitherto unnoticed indirect effect of ectoparasitism might be widespread in nature and

20 could affect our understanding of ecology and evolution of host-parasite interactions.

22 Keywords: ARISA, Bacterial community, Ectoparasite-host interactions, Hatching 23 success, Niche construction, Trans-shell transmission 


\section{Introduction}

25 Parasitism is widely recognized as one of the major selective forces driving the

26 evolution of host organisms [1-4]. Convincing demonstrations of the deleterious effects

27 that parasites impinge on fecundity and survival of their hosts come from a wide range

28 of parasite-host assemblages (e.g., [5-8]). Among them, interactions between

29 ectoparasites and birds have provided many influential and already classical examples

30 of parasite-mediated ecology and evolution of hosts [1, 3]. However, besides these

31 relatively well-documented direct deleterious effects on their hosts' fitness, little is

32 known about the role of ectoparasites as vectors or facilitating infection by

33 microparasites such as protozoa [9], viruses (e.g., [10-11]), or bacteria (e.g., [12, 13]),

34 which undoubtedly is highly important for disease ecology of avian populations.

35 Various arthropods, including fleas, adult and larval dipterans, mites, and ticks

36 feed on the blood of adult and nestling birds while in their nests [3, 14]. Actually, many

37 of these nest-dwelling ectoparasites develop, grow, and reproduce in their hosts' nests,

38 thus completing most of their life cycles in close contact with their hosts. As a

39 consequence, side-effects of this biological activity, such as skin injuries created by

40 blood-feeding, blood remains, or parasite faeces accumulate and modify nest

41 environmental conditions. This increase in nutrient availability may favour colonization

42 and growth of bacteria [15], some of which could be pathogens. As far as we know, this

43 potential role of ectoparasites as mediators of indirect interactions in nest environments

44 has never been explored.

45 Beyond their roles in disease as infectious agents [16], the importance of

46 bacteria in shaping ecology and evolution of higher organisms has been traditionally

47 neglected. Nevertheless, it has recently started to be subject of in-depth research from

48 an ecological and evolutionary framework (e.g., [17, 18]). Regarding interactions 
49 between bacteria and birds, it has been shown that different types of bacteria interact

50 with nestling growth $[19,20]$, may increase adult predation rates [21], and may be

51 involved for instance in the evolution of uropygial glands [22], plumage colouration or

52 maintenance [23-25], nest material composition [26, 27], incubation behaviours [28,

53 29], or even cognitive skills of birds [30]. Because of the important and diverse roles

54 that bacteria may play in the ecology and evolution of life histories and behaviour in

55 higher organisms (reviewed in [31-34]), detecting a causal link between ectoparasitism

56 and bacterial infections would contribute to the understanding of parasite-host

57 interactions.

58 In this study, we aimed to explore experimentally whether ectoparasites can

59 increase bacterial loads, or provoke changes in bacterial diversity and richness on hosts.

60 We manipulated abundance of a common, widespread and generalist ectoparasitic fly of

61 nesting birds (Carnus hemapterus Nitzsch) and evaluated subsequent changes in

62 bacterial loads, diversity and richness on eggshells of spotless starlings (Sturnus

63 unicolor Temminck). We hypothesized that faeces and blood remains accumulated on

64 eggshells because of the ectoparasite activity while feeding on incubating birds (Fig. 1)

65 would promote microbial colonization and growth on eggshells. In addition, we

66 hypothesized that this increased bacterial load or changes in diversity and/or richness on

67 eggshells may increase the chance of trans-shell bacterial infection, ultimately causing

68 embryo mortality and therefore a lower hatching success.

69

70 Materials and methods

71 Study area and species

72 The experiment was carried out during 2010-2011 breeding seasons (April-June) on

73 spotless starlings breeding in nest-boxes in two colonies (La Calahorra and Huéneja) 
74 located in Hoya de Guadix (Granada, Southern Spain, $37^{\circ} 18^{\prime} \mathrm{N}, 3^{\circ} 11^{\prime} \mathrm{W}$ ). Cork-made

75 nest-boxes (internal height $*$ width $*$ depth: $350 * 180 * 210 \mathrm{~mm}$, bottom-to-hole

76 height: $240 \mathrm{~mm}$, hole diameter: $6 \mathrm{~mm}$ ) were available for starlings, attached to tree

77 trunks or walls at 3-4 m above ground. Nest-boxes were cleaned before each breeding

78 season. Typical clutch sizes are four to five eggs in the population, females lay one per

79 day, and incubation usually starts one day before clutch completion and lasts 12-13 days

80 [35]. Immaculate blue eggs usually become brownish-spotted during incubation as a

81 result of the viscous faeces (and blood remains) that the ectoparasite Carnus

82 hemapterus (hereafter Carnus) deposits all around nests attached to substrates,

83 including bird skin, feathers, and eggs (Fig. 1a; [36-38]). Carnus is a $2 \mathrm{~mm}$ blood-

84 sucking fly found in nests of an extremely wide diversity of birds. So far, it has been

85 found parasitizing 64 host species from 24 different avian families, from raptors to

86 passerines [39-41]. It has been recorded throughout most of north America and Europe,

87 with more scarce records in Asia and north Africa suggesting that the distribution of this

88 parasitic genus is probably global, but yet undiscovered in most areas [39, 41]. Carnus

89 feeds mainly on nestlings, but also on incubating birds [36-38]. After emergence from

90 overwintering pupae inside nests, winged adults may disperse, losing their wings once a

91 suitable nest is found [40-42].

92

93 Experimental design

94 Nest-boxes were inspected every 4 days to detect initiation of egg laying by starlings,

95 and eggs were individually numbered with a permanent marker. As a standard protocol,

96 eggs were always handled with new sterile latex gloves further cleaned with $70 \%$

97 ethanol. Five days after laying of the first egg, we measured length and breadth of all

98 eggs with a digital calliper to the nearest $0.01 \mathrm{~mm}$, we estimated eggshell spottiness, 
99 and we sampled eggshell bacteria in one randomly selected egg (see below). Eggshell

100 surface area was estimated according to the formula: $S=(3.155-0.0136 * L+0.0115 *$

$101 B) * L * B$; where $S$ is surface in $\mathrm{mm}^{2}, L$ is egg length in mm and $B$ is egg breadth in $102 \mathrm{~mm}$ [43]. Then, nests were alternately assigned to the experimental or control treatments

103 (45 nests each; see Table 1 for distribution of nests between years and colonies). In

104 experimental nests, 10 unwinged Carnus flies collected from nearby nests were added 105 (which is within the natural infestation level in starling nests; [36, 37]; authors 106 unpublished data), while no flies were added in control nests. At the time of 107 manipulation, abundance of Carnus flies in nests was low in both groups, as shown by 108 reduced eggshell spottiness that also did not differ between treatments (see Results).

\section{Eggshell spottiness}

111 Estimations of eggshell spottiness (and bacterial sampling, see below) were performed

112 three times during the incubation period. The first one was carried out when incubation

113 had already commenced (on day five after laying of the first egg, immediately before

114 treatment assignment). Incubation is known to reduce eggshell bacterial load [28, 29].

115 Subsequent samplings were performed at middle (day nine) and late (day twelve)

116 incubation period. Egg spots, as indication of ectoparasite abundance [37], were counted

117 in every egg of each nest at the three visits. When egg spots were so abundant that

118 counting all spots became unfeasible, we estimated eggshell spottiness by counting

119 spots within a $1 \mathrm{~cm}^{2}$ on a random position along the shortest axis of the egg [37], which

120 was extrapolated to eggshell surface. We compared both estimates on a subsample of

121 eggs to confirm that both measures are correlated $\left(n=53, r^{2}=0.25, p<0.0001\right)$.

122 Within-nest mean eggshell spottiness per egg was used in the analyses, but excluding

123 the eggs that had been swabbed for bacterial sampling in previous visits (see below). 
125 Bacterial sampling

126 Eggshell bacteria were sampled by swabbing the whole surface of one egg (a randomly

127 selected egg in each of the three sampling times while avoiding previously sampled 128 eggs) with a sterile swab slightly wet with sterile phosphate buffer (PB, $0.2 \mathrm{M}$; $\mathrm{pH}=$ 129 7.2). The swab was preserved in a rubber-sealed microfuge tube containing $1.2 \mathrm{~mL}$ 130 sterile $\mathrm{PB}$, at $4{ }^{\circ} \mathrm{C}$ until bacterial culture analyses (within $24 \mathrm{~h}$ after collection), and then 131 frozen at $-80^{\circ} \mathrm{C}$ for posterior characterization of bacterial communities by ARISA (see 132 below).

\section{Estimation of bacterial density}

135 Eggshell bacterial density was estimated by mean of culture methods. Briefly, under 136 sterile conditions in the lab, bacterial samples were extracted after shaking the tubes in 137 vortex. Serial decimal dilutions up to $10^{-6}$ were cultivated by spreading $100 \mu \mathrm{L}$ of each 138 dilution in plates containing four different sterile solid growth media (Scharlau Chemie 139 S.A., Barcelona, Spain). We used a general medium (Tryptic Soy Agar; TSA) for 140 growing mesophilic bacteria, and three specific media: Kenner Faecal Agar (KF) for 141 growing bacteria belonging to the genus Enterococcus, Vogel-Johnsson Agar (VJ) for 142 bacteria of the genus Staphylococcus, and Hecktoen Enteric Agar (HK) for Gram143 negative bacteria of the family Enterobacteriaceae. Load of mesophilic bacteria on 144 eggshells is related to probability of trans-shell embryo infection [29, 44]. Enterococci 145 are opportunistic pathogens [45] also commonly found inside unhatched eggs [44]. 146 Staphylococcus and Enterobacteriaceae are saprophytic and opportunistic bacteria 147 commonly found on skin, feathers, and eggs of birds, with known pathogenic effects for 148 avian embryos $[44,46]$. Overall, these bacterial groups adequately characterize diversity 
149 of bacteria found on eggshells and are related to probability of trans-shell embryo 150 infection $[22,44]$. Plates were incubated at $37^{\circ} \mathrm{C}$ for $72 \mathrm{~h}$ and, afterwards, number of 151 colonies was counted. Bacterial load was estimated as CFU (Colony Forming Units) per $152 \mathrm{~cm}^{2}$ of sampled eggshell. For further details on bacterial sampling from eggshells, see $153[22,26]$.

154 Bacterial infections inside unhatched eggs, collected on day 4 after hatching of 155 the first egg, were also estimated by culturing the samples (only for 2011). After 156 disinfection of eggshell surface with disinfectant napkins (Aseptonet, Laboratoires 157 Sarbec, Neuville-en-Ferrain, France), a piece of the eggshell in the blunt end was 158 broken and the yolk and egg white were homogeneously mixed using a sterile 159 inoculation loop. Then, $300 \mu \mathrm{L}$ of the egg content were diluted in $300 \mu \mathrm{L}$ of $\mathrm{PB}$, from 160 which $100 \mu \mathrm{L}$ aliquots were cultured as above to detect internal bacterial infection [47, 161 48]. Presence of bacteria inside unhatched eggs cannot be unequivocally interpreted as 162 these bacteria causing hatching failure, but it reflects a higher probability of trans-shell 163 infection in comparison with eggs without bacteria inside [44, 47].

\section{Characterization of bacterial communities}

166 Bacterial communities of the eggshells were also characterized by molecular methods, 167 following the well-established ARISA (Automated rRNA Intergenetic Spacer Analysis) 168 protocol [49], which allows to identify different bacterial strains as operational 169 taxonomic units (OTUs) (see [50, 51] for further details). Bacterial genomic DNA was 170 extracted with Chelex-based DNA extraction protocol [52], and concentrated and 171 purified with centrifugal filter devices (Amicon Ultra-0.5, 100K device, Millipore). 172 ARISA amplifies the Intergenic Transcribed Spacer (ITS) region between the 173 prokaryotic $16 \mathrm{~S}$ and $23 \mathrm{~S}$ rDNAs. This region is highly variable both in size and 
174 sequence between species and strains [53]. The ITS region was amplified using the 175 primer pair ITSF (5'-GTCGTAACAAGGTAGCCGTA-3') and ITSReub (5'176 GCCAAGGCATCCACC-3') [54]. The primer ITSReub was labeled fluorescently with 177 6-FAM. Amplifications were performed in $50 \mu \mathrm{l}$ reaction volumes containing ultrapure $178 \mathrm{H}_{2} \mathrm{O}, 20 \mu \mathrm{l}$ of 5 PRIME MasterMix (2.5×) including $1.5 \mathrm{mM} \mathrm{Mg}(\mathrm{OAC})_{2}, 200 \mu \mathrm{M}$ $179 \mathrm{dNTPs}, 1.25 \mathrm{U}$ Taq DNA polymerase, $0.2 \mu \mathrm{M}$ of primers, and $5 \mu \mathrm{l}$ of concentrated 180 DNA. PCRs were conducted in the Eppendorf Mastercycler Nexus Family. Fragments 181 were amplified under the following conditions: initial denaturation at $94{ }^{\circ} \mathrm{C} 2 \mathrm{~min}$, 182 followed by 30 cycles with denaturation at $94{ }^{\circ} \mathrm{C} 45 \mathrm{~s}$, annealing at $52{ }^{\circ} \mathrm{C} 45 \mathrm{~s}$, and 183 extension at $72{ }^{\circ} \mathrm{C} 1 \mathrm{~min}$, with a final extension at $72{ }^{\circ} \mathrm{C} 5 \mathrm{~min}$. Amplified PCR 184 products were diluted 1:10 and denatured by heating in formamide. Fragment lengths 185 were determined by automated fluorescent capillary electrophoresis in a 3130 Genetic 186 Analyzer with GeneScan ${ }^{\text {TM }} 1200$ LIZ dye Size Standard (both Applied Biosystems). Peak Scanner 1.0 (Applied Biosystems) was used to determine fragment length

188 (in base pairs; bp) of each peak that enables the identification of different OTUs within 189 each sample. For methodological reasons, the estimated length of the same OTU from 190 different samples may differ slightly. Thus, binning DNA fragment lengths from 191 different samples is necessary before comparing bacterial communities. We did so by 192 using available scripts in $\mathrm{R}$ environment [http://cran.r-project.org/] at 193 http://www.ecology-research.com [55] with a window size of 3 bp and a distance of two 194 consecutive binning frames (i.e., shift) of 0.1 . The algorithm rearranges the data and 195 calculates the relative fluorescence intensity (RFI) of each peak by dividing individual 196 peak areas by the total peak area for the respective sample. All peaks with RFI values of $197<0.09 \%$ were not included in further analyses since they consisted of background 198 peaks. Only fragments above a threshold of 50 fluorescence units and ranging between 
199100 and $1000 \mathrm{bp}$ were taken into consideration so as to include the maximum number of

200 peaks while excluding background fluorescence [55]. We used the presence-absence

201 matrix generated after the binning process for the analyses of bacterial community.

202 Molecular fingerprinting techniques are highly reproducible and robust and have proven

203 useful for comparative analysis of microbial community structure [56, 57].

204

205 Estimation of egg viability and hatching success

206 Hatching success (proportion of eggs that hatched) was estimated by visiting nests daily

207 around expected hatching date. Egg viability before hatching was also recorded as a

208 complementary estimate of hatching success in 2011. Egg viability was recorded with a

209 device measuring embryo heart rate (Avitronics-Buddy Digital Egg monitor, Avian

210 Biotech International, Tallahassee, FL, USA) at late incubation (i.e., on the third

211 sampling day), and proportion of viable eggs was computed. Unfertile eggs (those with

212 no sign of embryo development) were discarded from subsequent estimations of egg

213 viability and hatching success. In cases where fate of some eggs was unknown, we

214 averaged possible outcomes (e.g., if 3 or 4 eggs out of 5 were known to hatch, then: $3 / 5$

$215=0.6 ; 4 / 5=0.8 ;$ hatching success $=0.7)$.

\section{Statistical analyses}

218 Eggshell bacterial loads were Box-Cox transformed before analyses. Analyses on log219 transformed variables for all bacteria, or on ranked values for Enterococcus, 220 Staphylococcus, and Enterobacteriaceae, provided the same qualitative results (data not

221 shown). To explore the effectiveness of the experiment in increasing ectoparasite 222 abundance, a repeated-measures ANOVA (rmANOVA) was carried out with values of 223 eggshell spottiness (Box-Cox transformed) at early, middle and late incubation as 
224 dependent repeated-measures variable, with treatment, year, and colony as factors, and

225 laying date as continuous predictor. Standardized laying dates relative to the first laying

226 date in each year and colony were used in analyses. To explore differences in bacterial

227 loads between treatments, a similar repeated-measures multivariate analysis of variance

228 (rmMANOVA) was carried out, with the four bacterial loads at early, middle and late

229 incubation as dependent repeated-measures variables, and the same predictors as above

230 (e.g., [26, 47, 58]). Including clutch size in analyses did not change the results.

Bacterial species richness (number of OTUs per sample) was Box-Cox

232 transformed before analyses. Analyses on log-transformed species richness provided the

233 same results. For some nests $(\mathrm{N}=58)$, bacterial richness at one or more of the sampling

234 times was not estimated because of failures during DNA extraction and/or ARISA

235 analysis. Thus, trying to use information from all sampled nests while considering the

236 repeated measured nature of the dataset, we used General Linear Mixed Model

237 (GLMM) with nest identity (nested within the interaction between year and treatment)

238 and the interaction between nest identity and sampling event (i.e. Time) as random

239 factors [59]. Study year was considered as a random factor, and Time (early, middle and

240 late incubation) and experimental treatment as fixed effects. All first order interactions

241 that included the study year (random factor) were considered as random factors, while

242 those including only fixed effects were considered as fixed factors. Colony was not

243 included as few data were available for one of the colonies (Huéneja) in 2010.

244 Beta diversity analyses to compare community composition between samples

245 (i.e. Principal Coordinate Analysis (PCoA) based on the Jaccard similarity matrix) were

246 performed using scripts from the Quantitative Insights Into Microbial Ecology software

247 (QIIME, version 1.9) pipeline [60] and R environment, and the EMPeror software for

248 graphic representations of the PCoA space [61]. We explored the effects of treatment, 
249 Time and its interaction by means of Procrustes ANOVA, a non-parametric test that 250 estimates the probability of shape variation attributable to one or more factors in a linear

251 model, via distributions generated from resampling permutations [62, 63]. We also

252 performed Trajectory Analysis in order to evaluate statistically the changes in trajectory

253 shapes in a multidimensional space. The first factor (treatment) defines groups and the

254 second one (Time) defines trajectory landmarks. Trajectory Analysis tests significant 255 changes in attributes of trajectory, as path distance, principal vector angles and 256 trajectory shape [64-67]. This analysis was performed twice, including all samples and 257 including only nests with bacterial data at the three sampling times (see above). As no 258 qualitative differences were found, we only show results that include all samples.

259 General Linear Models (GLM) were carried out with either proportion of viable 260 eggs or hatching success (both arcsine square-root-transformed) as dependent variable, 261 with treatment and colony as factors, year as random factor, and laying date as 262 continuous predictor, and these analyses were restricted to nests where egg failure was 263 observed. These two models were repeated replacing predictors by load of mesophilic 264 bacteria, prevalence of Enterococcus, Staphylococcus, and Enterobacteriaceae, and 265 bacterial species richness, at late incubation. Except for comparisons of community 266 composition, all other analyses were performed in STATISTICA 8.0, and statistical 267 models simplified by backward removing one by one non-significant terms with the 268 largest p-value.

\section{Results}

271 Nests under different experimental treatments did not differ significantly in laying date 272 or clutch size (both $p>0.50)$, with laying date being earlier in 2011 than in $2010\left(F_{1,88}\right.$ $273=4.93, p=0.029)$. As expected, eggshell spottiness was higher in experimental than in 
control nests (rmANOVA: $F_{1,86}=188.5, p<0.0001$ ) after controlling for the effect of

275 year $\left(F_{1,86}=30.90, p<0.0001\right)$. Eggshell spottiness did not differ between treatments

276 before the experiment, i.e., at early incubation (rmANOVA: post-hoc LSD test: $p=$ 277 0.29), and increased during incubation $\left(F_{2,172}=211.24, p<0.0001\right)$, but much more 278 markedly in experimental than in control nests (Time * Treatment interaction: $F_{2,172}=$ 279 131.91, $p<0.0001$, Fig. 2). Eggshell bacterial loads along the incubation period are shown in Table 2.

281 Eggshell bacterial loads were explained by experimental treatment (rmMANOVA: 282 Wilks' $\lambda=0.86, F_{4,83}=3.29, p=0.015$ ) after controlling for effect of year (Wilks' $\lambda=$ $2830.82, F_{4,83}=4.47, p=0.003$ ) and the positive effect of laying date (Wilks' $\lambda=0.63, F_{4,83}$ $284=12.11, p<0.0001)$. Bacterial loads did not differ between treatments before the 285 experiment, i.e., at early incubation (rmMANOVA: post-hoc LSD tests: $p>0.70$ ). 286 Treatment effect on bacterial loads did not vary significantly along the incubation 287 period (Time * Treatment interaction: Wilks' $\lambda=0.94, F_{8,79}=0.65, p=0.73$ ). With the 288 exception of Staphylococcus (post-hoc LSD test: $p=0.12$ ), all other bacterial types 289 were more abundant in experimental than in control nests (Enterococcus: $p=0.005$; 290 Enterobacteriaceae: $p=0.015)$, although not significantly so for mesophilic bacteria ( $p$ $291=0.10)$. Statistically significant differences were observed for Enterococcus at middle 292 (post-hoc LSD test: $p=0.038$ ) and late incubation $(p=0.045)$, and for 293 Enterobacteriaceae at middle incubation $(p=0.030)$ (Fig. 3).

294 We identified a total of 117 different OTUs in experimental nests and 105 OTUs 295 in control nests. OTU richness varied significantly along the incubation period in 296 relation to treatment (Time $*$ Treatment interaction: $F_{2,86}=3.47, p=0.036$ ). Species 297 richness did not differ between treatments before the experiment, i.e., at early 298 incubation (post-hoc LSD test: $p>0.59)$ nor at the end of incubation $(p>0.40)$. 
299 However, it was significantly higher in experimental than in control nests at middle 300 incubation ( $p=0.023$ ) (Fig. 4). Changes in bacterial community did not vary between 301 experimental and control nests nor along the incubation period (Procrustes ANOVA: 302 Treatment: $F_{1,168}=0.83, p=0.714$; Time: $F_{2,168}=0.11, p=0.227$; Treatment $*$ Time: $\left.303 F_{2,168}=0.66, p=0.979\right)$. Moreover, those changes showed similar patterns between 304 control and experimental nests (Trajectory Analysis: Path distances, pairwise absolute 305 differences between path distances $=0.005, p=0.92$; Principal Vector Angles, pairwise 306 angles $=74.72, p=0.49$; Trajectory Shape differences, pairwise shape differences $=$ $3070.17, p=0.386)$.

308 Experimental treatments did not explain differences in proportion of viable eggs 309 and hatching success (GLM: $p>0.3)$. However, proportion of viable eggs $\left(F_{1,7}=14.67\right.$, $310 p=0.006)$ and hatching success $\left(F_{1,25}=6.05, p=0.021\right)$ were lower in nests where 311 Enterobacteriaceae and Enterococcus, respectively, were detected at late incubation. In 312 addition, load of mesophilic bacteria at late incubation showed a negative relationship 313 with hatching success in nests with hatching failures $(n=39, r=-0.37, p=0.022)$. 314 Finally, no significant associations between presence of bacteria in eggshells at late 315 incubation and inside eggs were found for Enterococcus and Enterobacteriaceae ( $p>$ 316 0.8). However, trans-shell colonization of unhatched eggs by Staphylococcus was more 317 frequent in nests where these bacteria were detected on egg surface at late incubation (n $318=3 / 3)$ than where it was not $(n=3 / 14)\left(\chi^{2}{ }_{1}=6.68, p=0.010\right)$. Taken together, these 319 results suggest that increased eggshell bacterial loads might be related with increased 320 trans-shell infection, which ultimately may cause embryo mortality and reduce hatching 321 success.

\section{Discussion}


324 This is the first study, to our knowledge, showing that ectoparasitism affects bacterial

325 environment of nests of a wild bird. Our experiment shows that activity during

326 incubation of a common, generalist ectoparasite of a multitude of bird species in a wide

327 geographic range, increases abundance of different bacterial types and overall bacterial

328 species richness on spotless starling eggshells. This effect was detected just four days

329 after experimental addition of the Carnus ectoparasites and was reduced at late

330 incubation, probably matching a parallel reduction in eggshell spottiness of

331 experimental nests at late incubation due to incubation activity. This reduced effect at

332 the end of incubation may reflect adaptive behavioural or physiological defences by

333 birds to reduce ectoparasite and/or bacterial load during incubation [28, 29, 68, 69].

334 Nevertheless, no differences in bacterial community composition were detected between

335 treatments, suggesting that ectoparasites may not cause differences in bacterial

336 community of eggshells in general, but in bacterial abundance and species richness.

337 Although we did not detect a direct effect of experimental treatment on egg viability or

338 hatching success, variability in the capacity of incubating birds to reduce eggshell

339 bacterial loads might be the reason. In accordance with this possibility, we detected

340 correlational links between egg viability and hatching success with the presence of

341 Enterobacteriaceae and Enterococcus, respectively, at late incubation. Moreover,

342 hatching success was also lower in nests with a higher load of mesophilic bacteria,

343 while trans-shell colonization of eggs by Staphylococcus was more frequent in nests

344 where these bacteria were detected at late incubation than where it was not. A plausible

345 explanation for such results is that some incubating birds failed to control bacterial

346 growth caused by ectoparasite activity on eggshells, resulting in reduced hatching

347 success. Our experiment affected loads of Enterococcus, Enterobacteriaceae, and (not

348 significantly so) mesophilic bacteria, at middle incubation, and loads of Enterococcus at 
349 late incubation. These bacteria are known to reduce embryo viability, according to

350 extensive studies in poultry, and to more limited evidence in wild avian species (see

$351[22,28,29,44,70])$. While culture methods do not characterize the entire microbial

352 community, we selected the cultivation media to detect the most common groups of

353 bacteria inhabiting avian eggs and potentially causing embryo mortality [28]. We also

354 showed experimental effects of ectoparasite infestation on bacterial OTUs richness

355 estimated by molecular techniques. Thus, our experimental results demonstrated an

356 effect of ectoparasite activity on eggshell bacterial environment and a potential indirect

357 link with egg viability and hatching success.

358 An alternative explanation to our results could be that the parasites added 359 experimentally directly affected behaviour and/or condition of incubating females and,

360 thus, eggshell bacterial environment. Our experiment does not allow disentangling

361 indirect effects of ectoparasite activity through their faeces from direct effects of

362 ectoparasites on incubating birds. It would require collecting ectoparasite faeces for

363 manipulating eggshell environment without adding ectoparasites to the nests, an

364 experiment that would be logistically challenging. Whatever the mechanism involved,

365 our study ultimately shows that ectoparasites increase abundance and richness of

366 bacteria on eggshells, which might be potentially associated to a reduced hatching

367 success.

368 Only a handful of studies have suggested that ectoparasites may modify the nest

369 environment in a substantial manner. Heeb et al. [71] showed that fleas can increase

370 nest humidity and modify infestation patterns of other ectoparasites such as

371 Protocalliphora blowflies. Mennerat et al. [69] also pointed out that nests highly

372 infested by Protocalliphora blowflies are often wetter than usual, and reported a

373 correlation between abundance of this ectoparasite and bacterial density on feathers and 
374 skin of nestling birds. However, Mennerat et al. [69] did not manipulate parasite

375 abundance, so a common unmeasured third factor (e.g., nest humidity or temperature;

$376[71,72])$ may be responsible for abundance of both ectoparasite and bacteria. Our study

377 is the first to show experimentally a causal, direct relationship between ectoparasite

378 loads and bacterial loads and richness. This provides indirect support to ectoparasites

379 affecting reproductive success of hosts through indirect interactions mediated by

380 changes in eggshell bacterial environments.

381 This hitherto overlooked important effect of ectoparasitism may be widespread

382 in bird-ectoparasite systems, as other common and abundant nest-dwelling ectoparasites

383 of birds such as fleas, mites, and blowflies also develop and reproduce within the nest

384 matrix in close contact with eggs and nestlings, thereby likely creating the necessary

385 conditions for successful colonization and growth of potentially pathogenic

386 microorganisms. For example, there are known cases of spottiness on eggs or nest

387 environments apparently caused by fleas [73], bugs [74], mites Dermanyssus

388 gallinoides in hens Gallus gallus (G. Tomás, pers. obs.), or unidentified parasites [75-

389 77]. Further research involving other host and parasite species is therefore urged to

390 confirm the generality of the results presented in this study. The importance of bacteria,

391 the world's most abundant living beings, shaping ecology and evolution of wild

392 organisms has only recently started to be recognized [31-33, 78] and is changing the

393 way we interpret ecological interactions and animal biology [34]. Our study is an

394 example of how cross-disciplinary research may most benefit a proper comprehension

395 of interactions between parasites and their hosts $[18,79]$. The novel observation that

396 ectoparasites can modify bacterial communities living with their hosts may profoundly

397 affect our current understanding of disease transmission patterns and wildlife disease

398 ecology. 


\section{References}

1. Clayton DH, Moore J (1997) Host-parasite evolution: general principles and avian models. Oxford University Press, Oxford

2. Combes C (2001) Parasitism: the ecology and evolution of intimate interactions. The University of Chicago Press, Chicago

3. Loye JE, Zuk M (1991) Bird-parasite interactions. Ecology, evolution and behaviour. Oxford University Press, Oxford

4. Poulin R, Morand S, Skorping A (2000) Evolutionary biology of host-parasite relationships: theory meets reality. Elsevier, Amsterdam

5. Barber I, Hoare D, Krause J (2000) Effects of parasites on fish behaviour: a review and evolutionary perspective. Rev Fish Biol Fish 10:131-165

6. Degen AA (2006) Effect of macroparasites on the energy budget of small mammals. In: Morand S, Krasnov BR, Poulin R (eds) Micromammals and macroparasites: from evolutionary ecology to management. Springer-Verlag, Tokyo, pp 371-399

7. Møller AP, Allander K, Dufva R (1990) Fitness effects of parasites on passerine birds: a review. In: Blondel J, Gosler A, Lebreton J, McCleery RH (eds) Population biology of passerine birds. Springer-Verlag, Berlin, pp 269-280

8. Patterson JEH, Neuhaus P, Kutz SJ, Ruckstuhl KE (2013) Parasite removal improves reproductive success of female North American red squirrels (Tamiasciurus hudsonicus). PLoS ONE 8:e55779

9. Valkiūnas G (2005) Avian malaria parasites and other haemosporidia. CRC Press, Boca Ratón, Florida 
10. Gilbert L, Jones LD, Laurenson MK, Gould EA, Reid HW, Hudson PJ (2004) Ticks need not bite their red grouse hosts to infect them with louping ill virus. Proc R Soc Lond B 271:S202-S205

11. Naugle DE, Aldridge CL, Walker BL, Cornish TE, Moynahan BJ, Holloran MJ, Brown K, Johnson GD, Schmidtmann ET, Mayer RT, Kato CY, Matchett MR, Christiansen TJ, Cook WE, Creekmore T, Falise RD, Rinkes ET, Boyce MS (2004) West Nile virus: pending crisis for greater sage-grouse. Ecol Lett 7:704-713

12. Lobato E, Pearce-Duvet J, Staszewski V, Gómez-Díaz E, González-Solís J, Kitaysky A, McCoy KD, Boulinier T (2011) Seabirds and the circulation of Lyme borreliosis bacteria in the North Pacific. Vector Borne Zoo Dis 11:1521-1527

13. Staszewski V, McCoy KD, Boulinier $T$ (2008) Variable exposure and immunological response to Lyme disease Borrelia among North Atlantic seabird species. Proc R Soc Lond B 275:2101-2109

14. López-Rull I, Macías-Garcia C (2015) Control of invertebrate occupants of nests. In: Deeming DC, Reynolds SJ (eds) Nests, eggs, and incubation: new ideas about avian reproduction. Oxford University Press, Oxford, pp 82-96

15. Weiss MR (2006) Defecation behavior and ecology of insects. Annu Rev Entomol $51: 635-661$

16. Salyers AA, Whitt DD (2002) Bacterial pathogenesis. A molecular approach, 2nd edn. ASM Press, Washington, DC

17. Flórez LV, Biedermann PHW, Engl T, Kaltenpoth M (2015) Defensive symbioses of animals with prokaryotic and eukaryotic microorganisms. Nat Prod Rep 32:904

18. Hahn MA, Dheilly NM (2016) Experimental models to study the role of microbes in host-parasite interactions. Front Microbiol 7:1300 
19. Moreno J, Briones V, Merino S, Ballesteros C, Sanz JJ, Tomás G (2003) Beneficial effects of cloacal bacteria on growth and fledging size in nestling pied flycatchers (Ficedula hypoleuca) in Spain. Auk 120:784-790

20. Potti J, Moreno J, Yorio P, Briones V, García-Borboroglu P, Villar S, Ballesteros C (2002) Bacteria divert resources from growth for Magellanic Penguin chicks. Ecol Lett 5:709-714

21. Møller AP, Peralta-Sánchez JM, Nielsen JT, López-Hernández E, Soler JJ (2012) Goshawk prey have more bacteria than non-prey. J Anim Ecol 81:403-410

22. Soler JJ, Peralta-Sánchez JM, Martín-Platero AM, Martín-Vivaldi M, MartínezBueno M, Møller AP (2012) The evolution of size of the uropygial gland: mutualistic feather mites and uropygial secretion reduce bacterial loads of eggshells and hatching failures of European birds. J Evol Biol 25:1779-1791

23. Ruiz-Rodríguez M, Tomás G, Martín-Gálvez D, Ruiz-Castellano C, Soler JJ (2015) Bacteria and the evolution of honest signals. The case of ornamental throat feathers in spotless starlings. Funct Ecol 29:701-709

24. Ruiz-Rodríguez M, Valdivia E, Soler JJ, Martín-Vivaldi M, Martín-Platero AM, Martínez-Bueno M (2009) Symbiotic bacteria living in the hoopoe's uropygial gland prevent feather degradation. J Exp Biol 212:3621-3626

25. Shawkey MD, Pillai SR, Hill GE, Siefferman LM, Roberts SR (2007) Bacteria as an agent for change in structural plumage color: correlational and experimental evidence. Am Nat 169:S112-S117

26. Peralta-Sánchez JM, Møller AP, Martín-Platero AM, Soler JJ (2010) Number and colour composition of nest lining feathers predict eggshell bacterial community in barn swallow nests: an experimental study. Funct Ecol 24:426-433 
27. Ruiz-Castellano C, Tomás G, Ruiz-Rodríguez M, Martín-Gálvez D, Soler JJ (2016) Nest material shapes eggs bacterial environment. PloS ONE, 11:e0148894

28. Cook MI, Beissinger SR, Toranzos GA, Arendt WJ (2005) Incubation reduces microbial growth on eggshells and the opportunity for trans-shell infection. Ecol Lett 8:532-537

29. Cook MI, Beissinger SR, Toranzos GA, Rodriguez RA, Arendt WJ (2003) Transshell infection by pathogenic micro-organisms reduces the shelf life of nonincubated bird's eggs: a constraint on the onset of incubation? Proc R Soc Lond B $270: 2233-2240$

30. Soler JJ, Peralta-Sánchez JM, Martín-Vivaldi M, Martín-Platero AM, FlenstedJensen E, Møller AP (2012) Cognitive skills and bacterial load: comparative evidence of costs of cognitive proficiency in birds. Naturwissenschaften 99:111122

31. Archie EA, Theis KR (2011) Animal behaviour meets microbial ecology. Anim Behav 82:425-436

32. Benskin CMcWH, Wilson K, Jones K, Hartley IR (2009) Bacterial pathogens in wild birds: a review of the frequency and effects of infection. Biol Rev 84:349-373

33. Ezenwa VO, Gerardo NM, Inouye DW, Medina M, Xavier JB (2012) Animal behavior and the microbiome. Science 338:198-199

34. McFall-Ngai M, Hadfield MG, Bosch TCG, Carey HV, Domazet-Loso T, Douglas AE, Dubilier N, Eberl G, Fukami T, Gilbert SF, Hentschel U, King N, Kjelleberg S, Knoll AH, Kremer N, Mazmanian SK, Metcalf JL, Nealson K, Pierce NE, Rawls JF, Reid A, Ruby EG, Rumpho M, Sanders JG, Tautz D, Wernegreen JJ (2013) Animals in a bacterial world, a new imperative for the life sciences. Proc Natl Acad Sci USA 110:3229-3236 
35. Soler JJ, Navarro C, Pérez-Contreras T, Avilés JM, Cuervo JJ (2008) Sexually selected egg coloration in spotless starlings. Am Nat 171:183-194

36. Avilés JM, Pérez-Contreras T, Navarro C, Soler JJ (2009) Male spotless starlings adjust feeding effort based on egg spots revealing ectoparasite load. Anim Behav 78:993-999

37. López-Rull I, Gil M, Gil D (2007) Spots in starling Sturnus unicolor eggs are good indicators of ectoparasite load by Carnus hemapterus (Diptera: Carnidae). Ardeola 54:131-134

38. Tomás G, Martín-Gálvez D, Ruiz-Rodríguez M, Soler JJ (2017) Intraspecific avian brood parasites avoid host nests infested by ectoparasites. J Ornithol 158:561-567

39. Brake I (2011) World Catalog of the Family Carnidae (Diptera, Schizophora). Myia 12:113-169. (Updated in http://diptera.myspecies.info/files/Carnidae_catalog_0.pdf/; accessed 6 June 2013)

40. Calero-Torralbo MA (2011) Factores ecológicos y mecanismos implicados en la variabilidad de la interacción entre un ectoparásito generalista (Carnus hemapterus) y sus hospedadores. PhD dissertation, University of Granada, Granada, Spain

41. Grimaldi D (1997) The bird flies, genus Carnus: species revision, generic relationships, and a fossil Meoneura in amber (Diptera: Carnidae). American Museum of Natural History, New York

42. Mercier L (1928) Contribution à l'étude de la perte de la faculté du vol chez Carnus hemapterus Nitzsch, Diptère à ailes caduques. C R Hebd Seances Acad Sci $186: 529-531$

43. Narushin VG (2005) Egg geometry calculation using the measurements of length and breadth. Poult Sci 84:482-484 
44. Bruce J, Drysdale EM (1994) Trans-shell transmission. In: Board RG, Fuller R (eds) Microbiology of the Avian Egg. Chapman \& Hall, London, pp 63-91

45. Byappanahalli NM, Nevers MB, Korajkic A, Staley ZR, Harwood VJ (2012) Enterococci in the environment. Microbiol Mol Biol Rev 76:685-706

46. Krieg NR, Holt JG (1984) Bergey’s manual of systematic bacteriology. Williams \& Wilkins, Baltimore

47. Soler JJ, Peralta-Sánchez JM, Martínez-Bueno M, Martín-Vivaldi M, Martín-Gálvez D, Vela AI, Briones V, Pérez-Contreras T (2011) Brood parasitism is associated with increased bacterial contamination of host eggs: bacterial loads of host and parasitic eggs. Biol J Linn Soc 103:836-848

48. Wang JM, Firestone MK, Beissinger SR (2011) Microbial and environmental effects on avian egg viability: Do tropical mechanisms act in a temperate environment? Ecology 92:1137-1145

49. Fisher MM, Triplett EW (1999) Automated approach for ribosomal intergenic spacer analysis of microbial diversity and its application to freshwater bacterial communities. Appl Environ Microbiol 65:4630-4636

50. Martínez-García A, Soler JJ, Rodríguez-Ruano SM, Martínez-Bueno M, MartínPlatero AM, Juárez-García N, Martín-Vivaldi M (2015) Preening as a vehicle for key bacteria in hoopoes. Microb Ecol 70:1024-1033

51. Soler JJ, Martínez-García A, Rodríguez-Ruano SM, Martínez-Bueno M, MartínPlatero AM, Peralta-Sánchez JM, Martín-Vivaldi M (2016) Nestedness of hoopoes' bacterial communities: symbionts from the uropygial gland to the eggshell. Biol $\mathbf{J}$ Linn Soc 118:763-773 
52. Martín-Platero AM, Peralta-Sánchez JM, Soler JJ, Martínez-Bueno M (2010) Chelex-based DNA isolation procedure for the identification of microbial communities of eggshell surfaces. Anal Biochem 397:253-255

53. Danovaro R, Luna GM, Dell'Anno A, Pietrangeli B (2006) Comparison of two fingerprinting techniques, terminal restriction fragment length polymorphism and automated ribosomal intergenic spacer analysis, for determination of bacterial diversity in aquatic environments. Appl Environ Microbiol 72:5982-5989

54. Cardinale M, Brusetti L, Quatrini P, Borin S, Puglia A, Rizzi A, Zanardini E, Sorlini C, Corselli C, Daffonchio D (2004) Comparison of different primer sets for use in automated ribosomal intergenic spacer analysis of complex bacterial communities. Appl Environ Microbiol 70:6147-6156

55. Ramette A (2009) Quantitative community fingerprinting methods for estimating the abundance of operational taxonomic units in natural microbial communities. Appl Environ Microbiol 75:2495-2505

56. Bent SJ, Forney LJ (2008) The tragedy of the uncommon: understanding limitations in the analysis of microbial diversity. ISME J 2:689-695

57. Loisel P, Harmand J, Zemb O, Latrille E, Lobry C, Delgenès JP, Godon JJ (2006) Denaturing gradient electrophoresis (DGE) and single-strand conformation polymorphism (SSCP) molecular fingerprintings revisited by simulation and used as a tool to measure microbial diversity. Environ Microbiol 8:720-731

58. Møller AP, Flensted-Jensen E, Mardal W, Soler JJ (2013) Host-parasite relationship between colonial terns and bacteria is modified by a mutualism with a plant with antibacterial defenses. Oecologia 173:169-178

59. Quinn GP, Keough MJ (2002) Experimental design and data analysis for biologists. Cambridge University Press, Cambridge 
60. Caporaso JG, Kuczynski J, Stombaugh J, Bittinger K, Bushman FD, Costello EK, Fierer N, Pena AG, Goodrich JK, Gordon JI, Huttley GA, Kelley ST, Knights D, Koenig JE, Ley RE, Lozupone CA, McDonald D, Muegge BD, Pirrung M, Reeder J, Sevinsky JR, Tumbaugh PJ, Walters WA, Widmann J, Yatsunenko T, Zaneveld J, Knight R (2010) QIIME allows analysis of high-throughput community sequencing data. Nat Methods. 7: 335-336

61. Vázquez-Baeza Y, Pirrung M, Gonzalez A, Knight R (2013) EMPeror: A tool for visualizing high-throughput microbial community data. GigaScience 2:16

62. Collyer ML, Sekora DJ, Adams DC (2015) A method for analysis of phenotypic change for phenotypes described by high-dimensional data. Heredity 115:357-365

63. Goodall C (1991) Procrustes methods in the statistical analysis of shape. J Roy Stat Soc B-Method 53:285-339

64. Adams DC, Collyer ML (2007) Analysis of character divergence along environmental gradients and other covariates. Evolution 61:510-515

65. Adams DC, Collyer ML (2009) A general framework for the analysis of phenotypic trajectories in evolutionary studies. Evolution 63:1143-1154

66. Collyer ML, Adams DC (2007) Analysis of two-state multivariate phenotypic change in ecological studies. Ecology 88:683-692

67. Collyer ML, Adams DC (2013) Phenotypic trajectory analysis: comparison of shape change patterns in evolution and ecology. Hystrix-Ital J Mammal 24:75-83

68. Clark L (1991) The nest protection hypothesis: the adaptive use of plant secondary compounds by European starlings. In: Loye JE, Zuk M (eds) Bird-parasite interactions: ecology, evolution and behaviour. Oxford University Press, Oxford, pp 205-221 
69. Mennerat A, Mirleau P, Blondel J, Perret P, Lambrechts MM, Heeb P (2009) Aromatic plants in nests of the blue tit Cyanistes caeruleus protect chicks from bacteria. Oecologia 161:849-855

70. Cook MI, Beissinger SR, Toranzos GA, Rodriguez RA, Arendt WJ (2005) Microbial infection affects egg viability and incubation behavior in a tropical passerine. Behav Ecol 16:30-36

71. Heeb P, Kölliker M, Richner H (2000) Bird-ectoparasite interactions, nest humidity and ectoparasite community structure. Ecology 81:958-968

72. Dawson RD, Hillen KK, Whitworth TL (2005) Effects of experimental variation in temperature on larval densities of parasitic Protocalliphora (Diptera: Calliphoridae) in nests of Tree Swallows (Passeriformes: Hirundinidae). Environ Entomol 34:563568

73. McNeil, DAC Clark, F (1987) Markings on the eggs of house martins Delichon urbica. Bird Study 34:26-27

74. Krinsky WL (2002) True bugs (Hemiptera). In: Mullen G, Durden L (eds) Medical and veterinary entomology. Academic Press, San Diego, California, pp 67-86

75. Feare CJ, Constantine DAT (1980) Starling eggs with spots. Bird Study 27:119-120

76. Hornsby MAW, Fairn ER, Barber CA (2013) Male European starlings do not use egg spots as a cue to adjust investment in nestlings. Wilson J Ornithol 125:109-115

77. Jackson JA (1970) Spotted eggs in a local population of starlings. Bird Banding 41:308-310

78. Soler JJ, Martín-Vivaldi M, Peralta-Sánchez JM, Ruiz-Rodríguez M (2010) Antibiotic-producing bacteria as a possible defence of birds against pathogenic microorganisms. Open Ornithol J 3:93-100 
79. Tompkins DM, Dunn AM, Smith MJ, Telfer S (2011) Wildlife diseases: from individuals to ecosystems. J Anim Ecol 80:19-38 
Table 1 Distribution of experimental and control spotless starling (Sturnus unicolor) nests between different years and colonies

\begin{tabular}{llrr}
\hline Year & Colony & Control & \multicolumn{2}{c}{ Experimental } \\
\hline 2010 & La Calahorra & 7 & 6 \\
2010 & Huéneja & 5 & 6 \\
Subtotal & 12 & 12 \\
\hline 2011 & La Calahorra & 26 & 27 \\
$2011 \quad$ Huéneja & 7 & 6 \\
Subtotal & 33 & 33 \\
\hline Total & 45 & 45 \\
\hline
\end{tabular}


Table 2 Eggshell bacterial prevalence (proportion of infected nests) and loads (mean (SE) and range of colony forming units per $\mathrm{cm}^{2}$ ) at early, middle, and late incubation in experimental (Carnus-infested) and control starling nests

\begin{tabular}{|c|c|c|c|c|c|}
\hline & & & Prevalence & Mean (SE) & Range \\
\hline \multirow{8}{*}{ 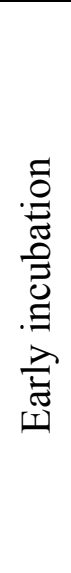 } & \multirow{4}{*}{ 吕 } & Mesophilic & $100 \%$ & $45059.6(28766.2)$ & $0.6-1210672.5$ \\
\hline & & Enterococci & $4.4 \%$ & $1.2(1.2)$ & $0-54.5$ \\
\hline & & Staphylococci & $13.3 \%$ & $0.1(0.0)$ & $0-1.8$ \\
\hline & & Enterobacteriaceae & $24.4 \%$ & $6288.2(4757.1)$ & $0-199761.0$ \\
\hline & \multirow{4}{*}{ 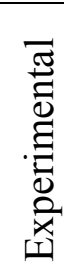 } & Mesophilic & $100 \%$ & $13110.0(10615.7)$ & $0.6-472860.5$ \\
\hline & & Enterococci & $6.7 \%$ & $12.9(10.0)$ & $0-424.4$ \\
\hline & & Staphylococci & $11.1 \%$ & $0.1(0.1)$ & $0-2.1$ \\
\hline & & Enterobacteriaceae & $26.7 \%$ & $8668.6(8621.0)$ & $0-387988.1$ \\
\hline \multirow{8}{*}{ 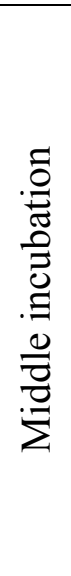 } & \multirow{4}{*}{ 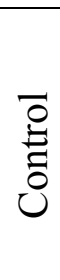 } & Mesophilic & $100 \%$ & $22870.5(22159.2)$ & $0.6-997607.2$ \\
\hline & & Enterococci & $6.7 \%$ & $1751.9(1722.9)$ & $0-77547.9$ \\
\hline & & Staphylococci & $8.9 \%$ & $1724.1(1723.3)$ & $0-77547.9$ \\
\hline & & Enterobacteriaceae & $13.3 \%$ & $1825.4(1377.2)$ & $0-57925.6$ \\
\hline & \multirow{4}{*}{ 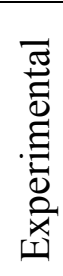 } & Mesophilic & $100 \%$ & $3012920.2(2169043.6)$ & $3.1-86200774.4$ \\
\hline & & Enterococci & $20.0 \%$ & $64.6(38.8)$ & $0-1609.8$ \\
\hline & & Staphylococci & $4.4 \%$ & $0.1(0.1)$ & $0-3.9$ \\
\hline & & Enterobacteriaceae & $31.1 \%$ & $699959.2(647193.4)$ & $0-29138289.9$ \\
\hline \multirow{8}{*}{ 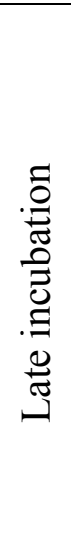 } & \multirow{4}{*}{ 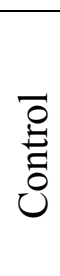 } & Mesophilic & $97.8 \%$ & $12540.4(7804.2)$ & $0-282480.4$ \\
\hline & & Enterococci & $11.1 \%$ & $2170.5(2085.8)$ & $0-93871.6$ \\
\hline & & Staphylococci & $13.3 \%$ & $9.8(9.3)$ & $0-417.2$ \\
\hline & & Enterobacteriaceae & $24.4 \%$ & $216.6(145.5)$ & $0-4906.8$ \\
\hline & \multirow{4}{*}{ 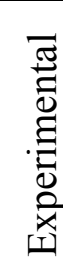 } & Mesophilic & $97.8 \%$ & $311939.0(290029.6)$ & $0-13056036.3$ \\
\hline & & Enterococci & $24.4 \%$ & $283.7(274.7)$ & $0-12369.0$ \\
\hline & & Staphylococci & $4.4 \%$ & $0.0(0.0)$ & $0-0.7$ \\
\hline & & Enterobacteriaceae & $35.6 \%$ & $13066.2(11124.0)$ & $0-496129.4$ \\
\hline
\end{tabular}


Figure legends

Fig. 1 Clutches of five different bird species from four different families showing natural levels of egg spottiness caused by accumulation of parasite faeces and host blood remains as a result of the activity of Carnus hemapterus parasites: a) spotless starling (Sturnus unicolor, family Sturnidae); b) hoopoe (Upupa epops, family Upupidae); c) Eurasian roller (Coracias garrulus, family Coracidae); d) little owl (Athene noctua, family Strigidae); e) Eurasian scops owl (Otus scops, family Strigidae). Note that unparasitized eggs of these species are of uniform, immaculate colours, i.e., blue in starlings and hoopoes (in hoopoes blue at laying and light brown later on) and white in rollers and owls (online version in colour)

Fig. 2 Effect of experimental addition of Carnus hemapterus flies on spottiness (number of spots per egg) of starling eggshells along the incubation period. Mean \pm SE values at early (before treatment), middle, and late incubation, for experimental $(n=45)$ and control nests $(n=45)$ are shown. Insets show representative eggs of Carnus-infested (above) and control clutches (below) (online version in colour)

Fig. 3 Effect of experimental addition of Carnus hemapterus flies on cultivable bacterial loads of starling eggshells. Mean \pm SE Box-Cox transformed counts of $(a)$ mesophilic bacteria, (b) Enterococci, (c) Staphylococci, and (d) Enterobacteriaceae, at early (before treatment), middle, and late incubation, for experimental $(n=45)$ and control nests $(n=45)$, are shown

Fig. 4 Effect of experimental addition of Carnus hemapterus flies on average number of OTUs (species richness) in starling eggshells. Mean \pm SE Box-Cox transformed counts at early (before treatment), middle, and late incubation, for experimental and control nests, are shown 
Figure 1

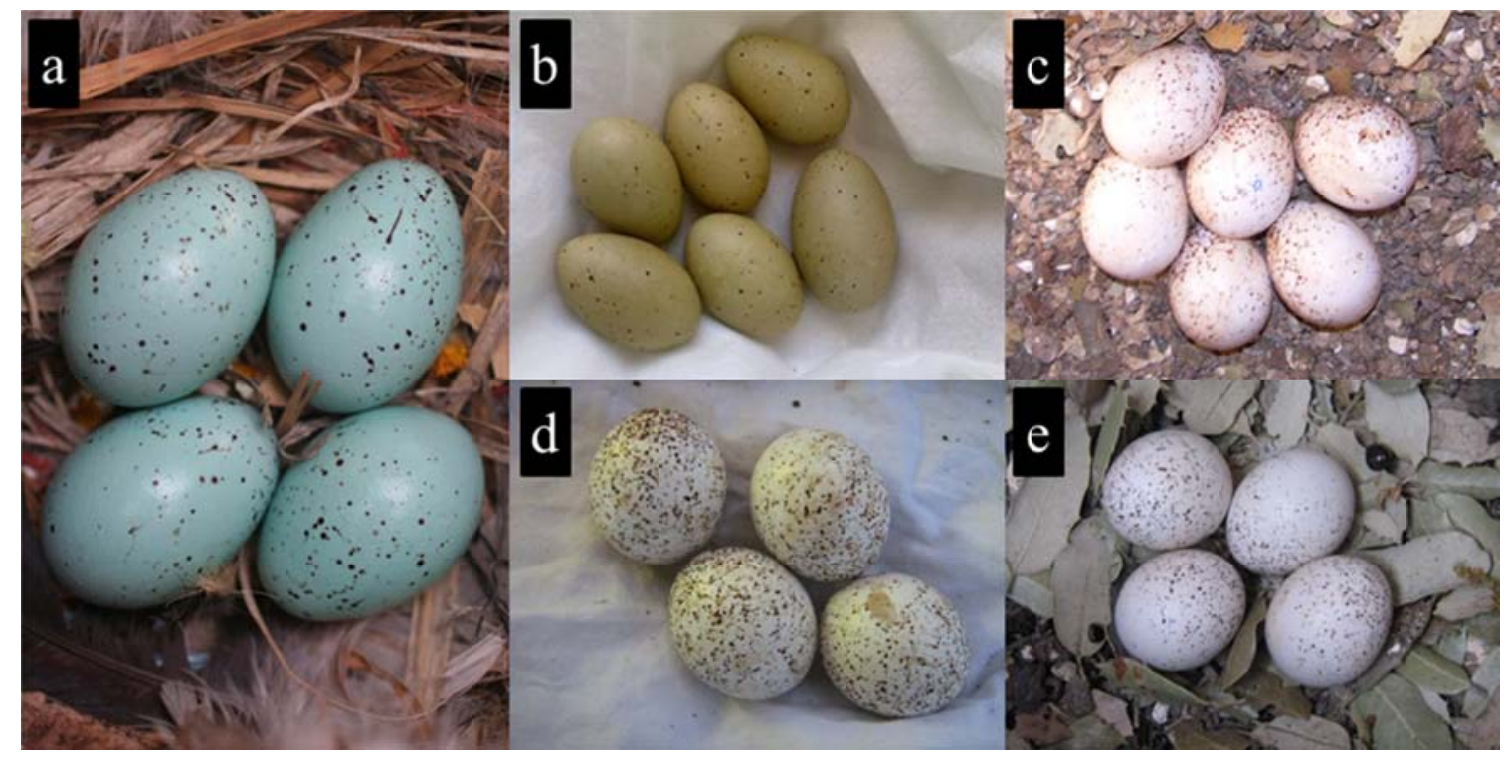


Figure 2

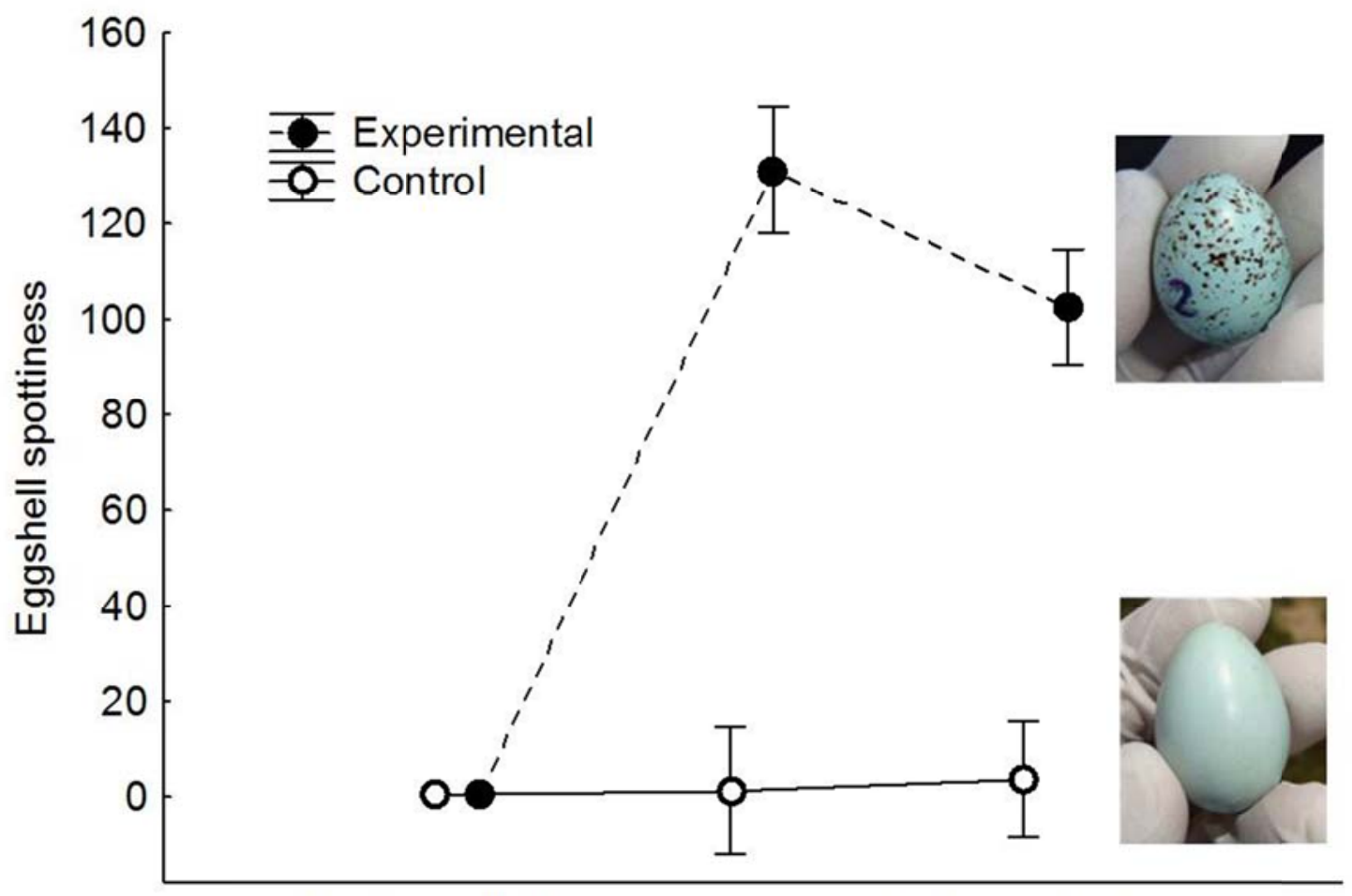

Early incubation

Late incubation

Middle incubation 
Figure 3
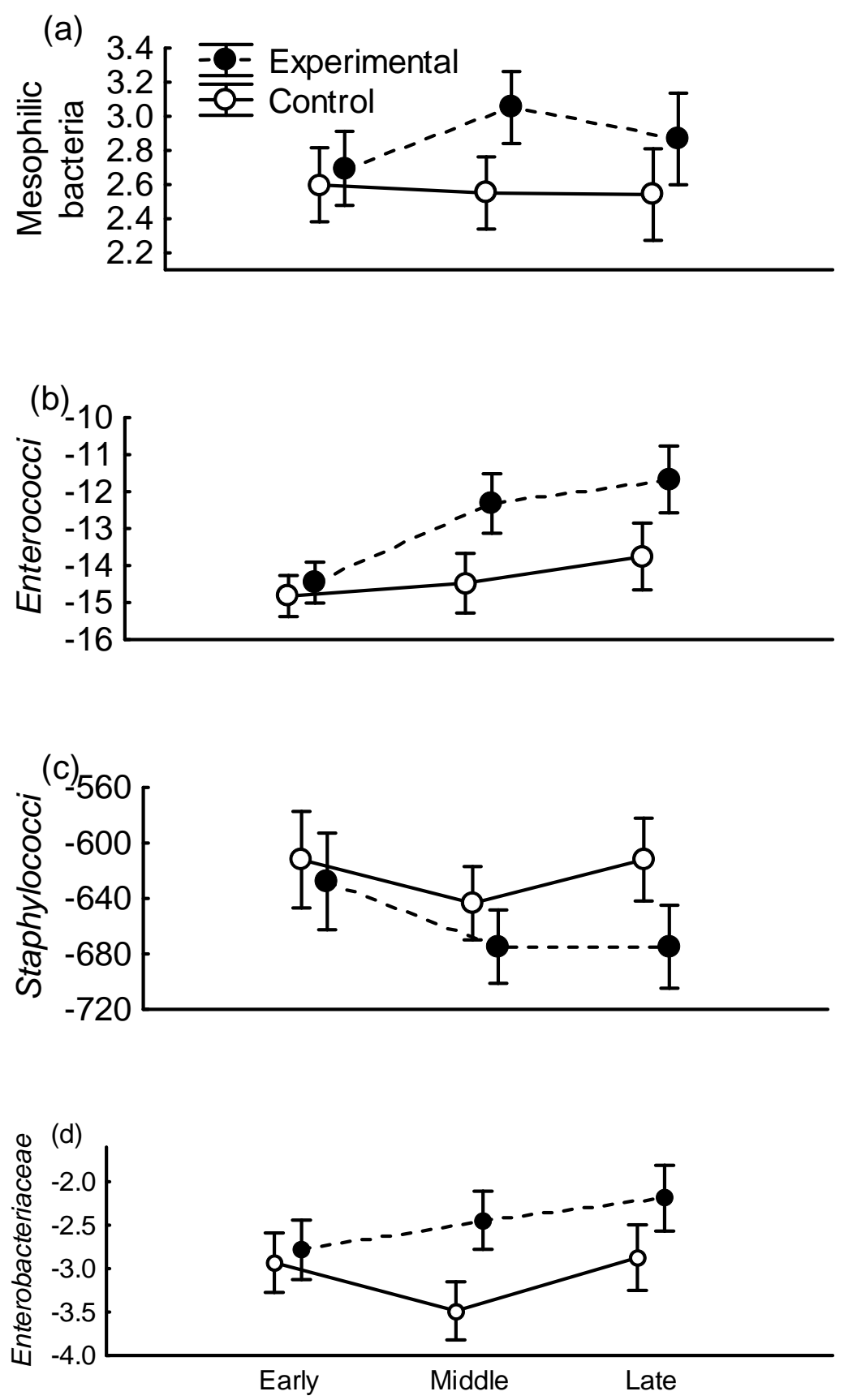
Figure 4

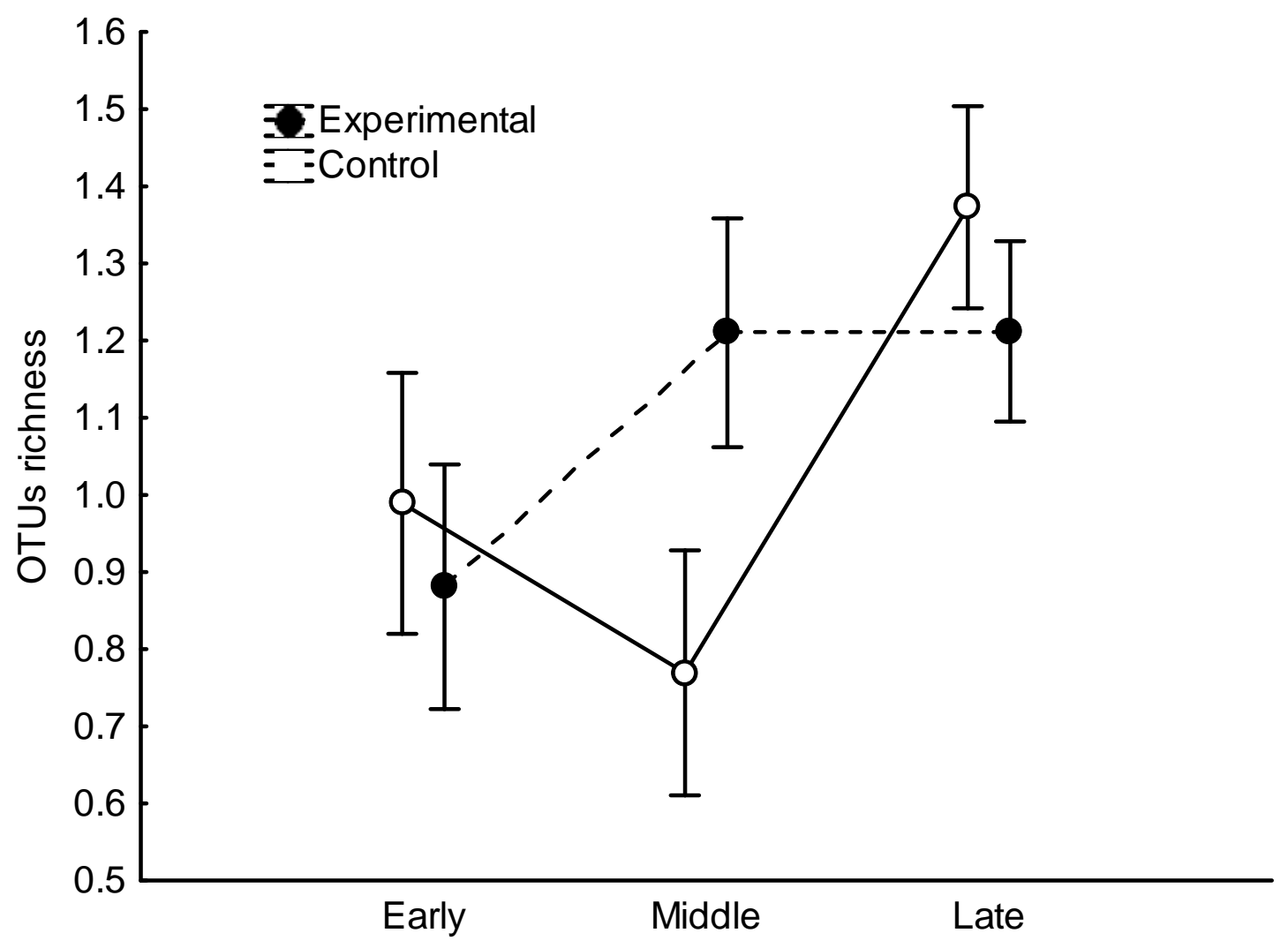

